\title{
Gender Violence, Suicide and Criminal Law
}

\author{
Yaíma Águila Gutiérrez* and Vicente Enrique Hernández Reyes \\ Department of Criminology, Cuba
}

*Corresponding author: Yaíma Águila Gutiérrez, Department of Criminology, Cuba.

Received Date: March 25, 2019

Published Date: April 12, 2019

\section{Review}

Pan-American Health Organization (PHO) has declared, about gender violence, that it is a problem which chiefly affects women. It has declared that at the end of 1990, gender violence had caused more death and incapacity to women from 15 to 44 years old than cancer, malaria, traffic accidents and war [1]. At the two last years of XX century, in Latin America, one of three sexual abuse cases were denounced and $80 \%$ were children and/or teenagers. About $30 \%$ y $50 \%$ of rape victims were younger than 15 years old and around $20 \%$ were younger than 10 years old, according to studies in Chile, Peru, Malaysia and United States of America Artiles [2]. At the same way, the World Health Organization (WHO) in 2012[3] expresses that violence against women and girls is a pandemic problem [4]. Also said that violence acts contribute towards the $15 \%$ of disease world charge [5]. Likewise, the Found of United Nations for Childhood, Science and Education (UNICEF) has been presenting reports for several years, according to gender violence as a problem that affects specially children Artiles [2]. Obviously, gender violence has become a main problem for humanity and no country is apart from that. It affects millions of people, mainly women and girls, but nobody is exempt of it [6].

Gender violence can be manifest from any social scene and anyone can cause or suffer it. There are two groups: macro or visible gender violence and non-visible gender violence, those can be classified as well in gender violence between people with the same gender or between different gender. The most common types of gender violence are physical, sexual, economic and psychological violence. Harmful effects of gender violence cause health damage and deterioration of relationships, reaching to commit a crime [7]. It is frequent to commit it in couple relationships [8-9].

Gender violence is a social problem which demands an intersectoral study because of the causes and consequences related to it and also affect human being and its relationship. Suicide is one of those consequences recognized by many theoretical and practical studies about gender violence. It is a common respond in front of gender violence. Some consulted researches recently show suicide as a health problem. According to the WHO, suicide is one of 20 more important death's causes in the world. Millions of people commit suicide almost every year; it is equivalent to one death every 40 seconds (WHO, 2018). It should be emphasize that suicide is the second mortal consequence because of couple violence. In addition, women who are ill-treated have three or five times more probability to commit suicide than others who does not suffer gender violence Martínez (2018). In accordance with Ángela Beatriz Martínez González [10], suicide in women as result of gender violence has increased to $166 \%$ in the last 10 years in Mexico. In Cuba, the suicide rate and suicide attempts are higher than any chronic diseases such as diabetes and/or liver diseases. Although our health system attends to victims of gender violence through primary health attention up to hospitals, the problem persists, because the factors which cause the violence are still present [11-15]. Therefore, a coactive mechanism is required in order to achieve a general prevention from Criminal Law, connected to those who provoke suicidal ideas in victims of gender violence [16-20].

It is required an interdisciplinary response from many sciences such as: social, education, medicine and law. From Criminal Law, can be demanded a penalty to those who practice gender violence and as result commit a crime. It is common that homicide, injuries and threats have been the result of gender violence. Suicidal idea could be the consequence of permanent submit to gender violence and many times it has no a legal response. Gender violence's victims receive the necessary help from primary health attention to hospitality attention, but in many cases, it is not enough because the cause is not eliminated. Then, it is also needed a mandatory mechanism which has prevention, it is possible from Criminal Law [21-25]. 


\section{Acknowledgement}

None.

\section{Conflict of Interest}

No conflict of interest.

\section{References}

1. Águila Gutiérrez, Y Hernández Reyes VE (2016) La interdisciplinariedad de la enseñanza - aprendizaje en la prevención de la violencia de género. Revista ATENAS 1 (33).

2. Artiles de León I (2012) Salud y violencia de Género. La Habana, Facultad de Ciencias Médicas Comandante Manuel Fajardo, Cuba.

3. WHO (2012) Recuperado en diciembre del 2018.

4. José Bueno M (2012) La Violencia de Género es un problema estructural de nuestra sociedad y nuestra cultura. Recuperado el.

5. López Cepero Borrego, J Rodríguez Franco, L Rodríguez Díaz, Fy Bringas Molleda C (2010) Ya no quisiera ni ser yo: La experiencia de la violencia doméstica.

6. Hernández Pita I (2014) Violencia de género. Una mirada desde la sociología. La Habana, Editorial Científico- Técnica, Cuba.

7. González Arenas, Pineda Contreras, González Daza, Serpa Santos y Callejas Pérez (2012) Violencia, Cuba.

8. Pick S, Leenen I, Givaudan, My Prado A (2010) Yo quiero, yo puedo... prevenir la violencia: programa breve de sensibilización sobre violencia en el noviazgo.

9. Valdés Jiménez YD (2012) Violencia de género en las familias Encrucijadas para el cambio. La Habana, La Habana, Acuario, Cuba.

10. Martínez González AB (2018) Intento de suicidio en mujeres victimas de violencia familiar en el sureste de méxico: el caso tabasco, voces y experiencias.
11. Barragán K (2012) Cortejo.

12. Calvo González, Gy Camacho Vejarano R (2014) La violencia de género: evolución, impacto y claves para su abordaje.

13. Cano P, Gutiérrez C, Nizama M (2009) Tendencia a la violencia e ideación suicida en adolescentes escolares en una ciudad de la amazonía peruana.

14.de Beauvoir S (2000) El segundo sexo. In: Id Madrid (Edt.), Valencia: Cátedra Universitaria de Valencia, Spain.

15. García Córdova A, Valdés Jiménez Y (2012) Violencia de género en las familias. In: Primera, La Habana (Edt.), Publicaciones Acuario, Cuba.

16. Gonzalez A, Castellanos BY (2003) Sexualidad y géneros. Alternativas para su educación ante los retos del siglo XXI. La Habana: Editorial Científico Técnica, Cuba.

17. Lehrer JA (2015) La violencia sexual y en el cortejo en personas jóvenes: Problemas que requieren más atención.

18. Moreno Álvarez LY (2004) Caracterización del adolescente del nivel secundario. La Habana, Cuba.

19. Peña Ovejas EY, Fernández Martínez C (2011) El abuso sexual en la infancia. Cómo prevenirlo y detectarlo desde el ámbito educativo.

20. Pick Susan IL (2010) Yo quiero, yo puedo...prevenir la violencia: programa breve de sensibilización sobre violencia en el noviazgo.

21. Póo AM, Vizcarra BY (2008) Violencia de Pareja en Jóvenes Universitarios. 22. UNESCO (2015).

23. Villalpando Acuña, A Modelando el cortejo humano: negociación e intercambio en las relaciones de parejas desde la perspectiva de la sociología económica.

24. Weber C (2012) La violencia en el mundo actual.

25. MINSAP (2018). 